QNueva Etinexaxia Revista Digital de OFilosofia ISSN 1850-3578 2013 - Vol. 8 - Número VIII - Resistencia, Chaco, Argentina. Pp. 58 - 90

\title{
La problemática idea de la semiótica cinematográfica
}

\author{
Alberto J. L. Carrillo Canán ${ }^{1}$ \\ Benemérita Universidad Autónoma de Puebla (México)
}

Recibido: 08/06/2013

Aceptado: $21 / 07 / 2013$

El cine “(...) puede ser considerado como un lenguaje en la medida en la que ordena elementos significantes en arreglos estructurados (...) que no tienen correspondencia en la configuración perceptiva de la realidad misma (...)" (Metz), como ocurre con la "lengua hablada" (Metz).

“La manipulación fílmica transforma en discurso lo que podría haber sido una mera transferencia visual de realidad [a la pantalla]. Derivado de una significación que es puramente análoga y continua (...), el cine conformó gradualmente algunos elementos de una auténtica semiótica (...)" (Metz).

“(...) el único principio (...) capaz de definir (...) la semiótica del cine es (...) el deseo de tratar a los filmes como textos, como unidades de discurso (...)" (Metz).

"Es bien sabido que la naturaleza del cine es transformar el mundo en discurso." (Metz)

En el mundo académico anglosajón la semiótica como esquema teórico que pretende ser el principio de la comprensión y explicación de los fenómenos de la cultura en su totalidad está prácticamente desaparecida. Sin embargo por razones de la historia de las ideas que merecen una consideración aparte pero que no podemos emprender aquí, en Latinoamérica la semiótica y sus pretensiones explicativas omniabarcantes tienen una notable vitalidad. En particular, mientras que la teoría del cine dominante en la actualidad en el mundo anglosajón es cognitivista, en Latinoamérica todavía es muy influyente la teoría narratológica del cine como versión específica de la teoría semiótica. El centro de toda teoría semiótica de la cultura

\footnotetext{
1 acarrillo_mx@yahoo.com

${ }^{2}$ A menos que se indique lo contrario, todos los énfasis en las citas son nuestros.
} 
es el concepto de "código" y otros relativos a él como "lenguaje", "mensaje", "comunicación", "discurso" y "texto". En particular ocurre que siempre que se habla de los "códigos cinematográficos", aparecen en seguida las nociones concomitantes de lenguaje, mensaje, discurso y texto "cinematográficos". El objetivo de este trabajo es apuntar a los problemas de principio de la teoría semiótica del cine cuestionando la noción de los "códigos cinematográficos", de la existencia misma de dichos códigos. Al hilo de esta crítica daremos argumentos que bien pueden ser considerados parte de una aproximación cognitivista al fenómeno fílmico y también como un cuestionamiento general a la pertinencia de la semiótica en tanto teoría general de los signos que pretende abarcar la inteligibilidad en general, en particular la que permite la experiencia fílmica.

\section{Observaciones básicas}

Gracias a autores como Barthes, el intento de explicar los fenómenos culturales en términos semióticos recibió un gran impulso, de tal manera que se volvió común hablar del "lenguaje de la moda" o del "lenguaje culinario", para mencionar solamente unos ejemplos, y en este contexto expresiones como la de "lenguaje corporal" o "lenguajes de la pintura" se volvieron habituales y aparentemente autoevidentes, naturales. ${ }^{3}$ Así, las posiciones y movimientos corporales, "comunican" o "dicen" cosas, emiten "mensajes". Para principiar nuestra problematización de las pretensiones teóricas de la semiótica, en este trabajo tomamos ya desde el principio la siguiente posición, a saber, "mensajes" y "comunicación" en sentido estricto solamente los hay cuando se utiliza un código en sentido igualmente estricto; solamente cuando se utiliza un código en sentido propio es que se "dicen" cosas o se "emiten mensajes". Para ilustrar la tesis básica recién mencionada tomemos el asunto aparentemente trivial del pretendido "lenguaje corporal" y sus supuestos "mensajes".

Cuando alguien se muestra inseguro en sus movimientos, digamos, no está "diciendo" nada ni "emitiendo" ningún "mensaje". Simplemente por experiencia vital el observador reconoce en la actitud corporal de la persona bajo escrutinio que la misma está insegura, y eso es todo. Gracias a nuestra experiencia vital, a partir de la apariencia de una persona podemos reconocer con cierta certeza cuando alguien está cansado, cuando está nervioso, irritado, impaciente, contento, entusiasmado, etc. De hecho, a los interrogadores policiacos y a otros agentes de seguridad y de espionaje se les entrena para saber distinguir gestos menos sencillos de percibir, como dilataciones de las pupilas, ritmo y manera de respirar, ligerísimos

\footnotetext{
${ }^{3}$ Paradigmático en este contexto sería el libro de Barthes, FS, en el cual encontramos expresiones como "el carácter sintáctico del signo vestimental" (FS 213), por ejemplo. Para las abreviaturas y la bibliografía véase la lista al final de este trabajo
} 


\section{Q Nueva Etinexaxio Revista Digital de OFilosofla ISSN 1850-3578}

2013 - Vol. 8 - Número VIII - Resistencia, Chaco, Argentina. Pp. 58 - 90

movimientos de los párpados y las comisuras de la boca, cambios muy sutiles en la tensión muscular, y otros del mismo orden. Aún suponiendo que tales elementos - y nos guardamos aquí de llamaros signos, indicios, etc. - fueran específicos de una cultura dada y no generales a los seres humanos, su "significado" se conoce por la práctica, por la simple experiencia, de "cómo son las cosas" y no porque uno sea introducido, iniciado en un código como conjunto de reglas arbitrarias de combinación de elementos igualmente arbitrarios como lo son las reglas sintácticas y los elementos de un léxico, digamos el español, del alemán o del código morse o el de las señales de navegación emitidas por medio de banderolas, todos estos verdaderos códigos en el sentido estricto del término "código".

Nos acabamos de referir al "significado" de los movimientos y ciertos otros elementos corporales, y tal término puede ser ya bastante problemático si no se precisa. Con esto llegamos a nuestra segunda observación básica. Partimos de que hay que distinguir dos tipos de inteligibilidades, de "sentidos" o "significados", a saber, las inteligibilidades "naturales", es decir, aquellas que proceden de la simple experiencia vital de "cómo son las cosas", de "cómo es el mundo", por un lado y, por otro, las inteligibilidades artificiales de los mensajes generados a partir de los códigos en sentido estricto en tanto sistemas diseñados ex profeso para comunicar. Así, una fumarola moviéndose en cierta dirección "significa" que el viento va en esa dirección, con base en nuestra experiencia la fumarola nos hace comprender que el viento sopla hacia donde ella va; es la simple experiencia la que hace inteligible esta situación, pero la fumarola moviéndose no "dice" nada ni "da" ningún "mensaje". Pero lo mismo ocurre con la cara - dependiendo de la situación - ruborizada por la pena o enrojecida por la ira o incluso por una alteración meramente fisiológica y no emotiva en lo absoluto. El rubor facial no "dice" nada ni da ningún "mensaje" en sentido estricto, tampoco "comunica" nada; simplemente a partir de él inferimos algo con base en nuestra experiencia de cómo son las cosas. Lo mismo vale para las pupilas dilatadas o las manos que tiemblan ligeramente o los músculos que se tensan de manera apenas perceptible. No comunican nada pero, con la experiencias suficiente, nos permiten inferir cosas, es decir, hacer inteligible una situación.

Para subrayar más claramente la distinción entre la inteligibilidad natural del mundo - así sea cultural - y la inteligibilidad codificada de los mensajes propiamente dichos, pensemos en el caso del individuo que le dice a su pareja que no quiere que hable con otras personas, que le exige que siempre que la llame por teléfono le conteste, que le demanda "estar en casa" a cierta hora, etc. Tal individuo no está ni "diciendo", ni "comunicando", ni "emitiendo el mensaje" de que es celoso. Su pareja, y cualquier observador o enterado de tales demandas, infiere por simple experiencia vital que el individuo es celoso, muy celoso - por lo menos eso - 
. A pesar de que el individuo en cuestión se comporta verbalmente, dice cosas, las comunica, emite mensajes, simplemente ni dice, ni comunica, ni emite el mensaje de que es celoso. Tal vez tampoco quiere "darlo a entender", pero lo cierto es que cualquier persona con un poco de experiencia se da cuenta, infiere que el individuo es celoso, su disposición a los celos se revela o se hace inteligible de manera puramente natural, a pesar de que toda la situación está mediada por el uso de un código lingüístico y a pesar de que los celos sean un fenómeno circunscrito a ciertas culturas y no universal. En este caso, dado que todo está mediado por la verbalidad, la inteligibilidad de la situación requiere para el que la comprende, en particular para la pareja del individuo, el dominio del código lingüístico utilizado en la comunicación, pero es la experiencia vital no el dominio del código lingüístico lo que permite hacer la inferencia de que el sujeto es celoso, cosa que no es el contenido de ninguno de sus mensajes. Por el contrario, el sujeto puede muy bien no decir otra cosa más allá de que es celoso, en este caso sí que hay el mensaje o la comunicación correspondiente, y la comprensión del hecho, de la situación, de que el tipo es celoso no se basa en ninguna inferencia a partir de la experiencia de cómo es el mundo sino que es el contenido directo del mensaje, el mensaje mismo es algo que es inteligible como comprensión de un mensaje gracias al dominio del código lingüístico y ya.

Distinguimos, pues, entre la inteligibilidad o significado de los auténticos mensajes, de la verdadera comunicación, basada en el uso de códigos especialmente construidos o generados para "decir" cosas, por un lado y, por otro, la inteligibilidad de "sentidos" o "significados" de elementos o situaciones del mundo que se basan en inferencias hechas a partir de la experiencia, donde nadie dice nada ni desea comunicar nada sino que simplemente alguien genera, o se genera de manera espontánea, una situación de inferencia que, también, permite orientarse en el mundo, que le da sentido a este pero no significado. Un último ejemplo puede hacer más clara la diferencia que nos interesa aquí.

El problema que es necesario considerar en este momento es el de las situaciones de inferencia generadas intencionalmente y que fácilmente pueden ser tomadas por "mensajes" o "comunicados", confundidas con que alguien "diga" algo. En realidad se trata de que se da a entender algo sin decir nada sino simplemente generando una situación de inferencia. Un caso tal sería el de alguien que intencionalmente deja un rastro o una huella, por ejemplo, una rama quebrada en el bosque. En este caso se podría tener al guía de muchachos exploradores que quiere que sus pupilos puedan seguir su rastro, pero también podría tratarse de alguien que es perseguido y que deja "huellas falsas" para despistar sobre su verdadera ruta. En ambos casos hay una intención, pero no una intención propiamente comunicativa como 
eNueve Otinenaxio Revista Digital de Filosofia ISSN 1850-3578 2013 - Vol. 8 - Número VIII - Resistencia, Chaco, Argentina. Pp. 58 - 90

cuando se dice algo, sino la intención de generar una situación de inferencia. En otras palabras, podemos suponer que - salvo casos excepcionales como cuando alguien dice algo irreflexivamente y luego se arrepiente - el uso se códigos es intencional, a saber, intencionalmente se codifica un mensaje, se comunica, se dice realmente algo utilizando el instrumento especial que es un código en el sentido estricto que comprende los elementos que forman un "léxico" y reglas de combinación de dichos elementos las cuales forman una "sintaxis". La inteligibilidad de la codificación supone en general el uso intencional de un código. Por el contrario, la inteligibilidad natural que caracteriza a las inferencias realizadas con base en la experiencia de cómo son las cosas, puede o no tener un intensión atrás de ella, pero ni aún en el caso de que intencionalmente se genere una situación de inferencia es apropiado decir que se comunica algo, que se emite un mensaje. A lo más, en el caso de la creación intencional de una situación de inferencia se puede decir que alguien "da a entender algo" pero sin comunicar o decir nada, ya que se recurre a la inteligibilidad natural y no a la codificada. El entender mensajes requiere el aprendizaje de instrumentos especiales llamados códigos, mientras que el entender el mundo, el orientarse en él haciendo inferencias, requiere solamente de una inteligibilidad espontánea proveniente de la experiencia vital. ${ }^{4}$

A partir de las reflexiones anteriores descartamos como inapropiados los conceptos de código, mensaje, comunicación, texto, discurso y, especialmente, lenguaje, para las inteligibilidades naturales que permiten una orientación en el mundo, ya sea natural o cultural, a partir de las simples capacidades humanas de inferir de la experiencia.

\section{El problema básico de la semiótica}

\footnotetext{
${ }^{4}$ Por su parte Metz, la figura guía de la teoría semiótica cinematográfica, distingue entre "códigos culturales" y "códigos especializados" (FL 112) y gran parte de lo que nosotros llamamos inteligibilidad natural él la consideraría como relativa a los "códigos culturales" que serían aprendidos "(...) sin más entrenamiento que el mero vivir y el haber sido educado en una sociedad." (FL 112). Por razones de espacio no podemos abordar en este trabajo la confusión de Metz entre la experiencia relativa a la vida en una cultura, o en otro entorno cualquiera, por un lado y, por otro, auténticos códigos relativos a una cultura. Metz - como muchos semióticos y antropólogos - confunde ambas cosas. En cualquier caso, lo que nosotros llamamos aquí códigos es lo que Metz llama "códigos especializados", cuyo dominio necesita de "entrenamiento especial" (FL 112) que solamente aparecerían "más explícitamente como códigos" (FL 112) que aquella inteligibilidad que nosotros hemos llamado natural. Para Metz se trata de una diferencia de grado, de manera tal que por lo menos dentro de una cultura parecería no haber nada que sea una inteligibilidad natural. Aquí nos hemos referido a Metz, lo cual de hecho prepara nuestra discusión posterior, pero la posición de Metz es la posición estándar en la teoría semiótica y gran parte de la antropología así como en lo que ahora se llama "estudios culturales". Por supuesto, el entrenamiento especial al que refiere Metz es el aprender un código, y es algo muy diferente del entrenamiento de un radiólogo que reconoce problemas de salud con base en placas de rayos $\mathrm{X}$, o bien del técnico que reconoce estados de órganos a partir del ultrasonido. Estos últimos especialistas realmente necesitan de un entrenamiento, pero ellos tampoco descifran ningún mensaje, ni el cuerpo les comunica absolutamente nada.
} 
La semiótica entendida como la "ciencia general de los signos" o de las "significación" resulta cuestionable por su búsqueda incansable de códigos atrás de, por lo menos, todos los fenómenos de la cultura, lo que equivale a ver en todos los hechos y objetos culturales un "mensaje", una "comunicación" realizada con base en un "lenguaje" - al que para simplificar podemos aquí hacer equivalente a la existencia de un código -. Atendiendo a las consideraciones hechas arriba, la búsqueda incansable de los códigos en un esfuerzo semiótico generalizado, equivale a reducir toda la inteligibilidad a la inteligibilidad artificial de los códigos, a desconocer la amplísima inteligibilidad que proviene de la simple experiencia vital y que, según quedará claro más abajo, no se reduce a la capacidad de hacer inferencias -. En realidad este problema tiene un origen doble, el cual, simplificando de una manera radical, podemos decir que es una mezcla del impulso peirceano y del impulso saussureano, llevando ambos más allá de los límites que tanto Peirce como de Saussure se impusieron cada uno a sí mismo.

Peirce nos presenta una ampliación extraordinaria, realmente omniabarcante, del concepto semiótico básico, a saber, del concepto de signo. Ya en la versión simplificada de su teoría explícita de los signos ${ }^{5}$ Peirce reserva el concepto de "símbolo" para los elementos de un léxico y para los mensajes en sentido estricto, es decir, para las inteligibilidades articuladas a partir del uso de un código y para los elementos léxicos estructurados en ellas. Pero al introducir el concepto de "icono" para lo que Hume llamaría asociación de ideas por semejanza y también el concepto de "índice" para lo que el mismo Hume llamaría asociación de ideas por cercanía o conexión, ${ }^{6}$ Peirce interpreta la totalidad de la inteligibilidad como un problema sígnico, es decir, semiótico. $Y$ a pesar de lo celebrada que ha sido la tricotomía sígnica de Peirce en "símbolo", "icono" e "índice", tal tricotomía tiene una desventaja básica, a saber, que es realmente omniabarcante de la realidad y, justamente por ello, rompe con el buen sentido común que llevó a la distinción tradicional entre cosas y signos.

El sentido común repara en el hecho básico de que el hombre se confronta con dos tipos de entidades completamente diferentes, a saber, con las cosas que sirven para algo por sí mismas y con las cosas que sirven solamente en relación con otras en tanto que son signos de aquellas. ${ }^{7}$ Las entidades que no son signos son absolutas comparadas con las entidades que son signos ya que estas son relativas a aquellas. En términos de ontología de sentido común,

\footnotetext{
${ }^{5}$ Véase el famoso artículo “¿Que es un signo?”, por ejemplo en EP.

${ }^{6}$ Véase "On the Association of Ideas", en EU 16s.

7 Podríamos decir que ya en el diálogo Crátilo, Platón asimila tanto las artes imitativas o representativas y el lenguaje bajo el concepto de signo, en la medida en que una representación mimética, así como las palabras remiten a otra cosa, aquella de manera natural, estas de manera convencional.
} 
Q Nueva Etinexaxio Revista Digital de OFilosofla ISSN 1850-3578 2013 - Vol. 8 - Número VIII - Resistencia, Chaco, Argentina. Pp. 58 - 90

una cosa no remite a nada más que a ella misma mientras que un signo remite a una cosa que es su significado - así sea esta cosa una idea -. No interesa entrar aquí en complejos detalles y distinciones sobre el origen del concepto de signo sino únicamente subrayar que tenía un carácter ontológico consistente en distinguir entre cosas "normales" y esas otras cosas muy especiales que son los signos. Pero Peirce semiotizó todo y acabó con el buen sentido común atrás de la venerable distinción entre cosas y signos. Sin embargo, habrá que señalar que la ampliación universal del concepto de signo realizada por Peirce es apenas uno de dos elementos en las pretensiones pansemióticas de las semiótica como ciencia general de los signos incluyendo a los fenómenos de la cultura. El otro elemento que se requiere para lo que en ocasiones se ha llamado el "imperialismo semiótico"8 es el concepto de "código", y habrá que señalar que a pesar de su concepto universalizante de signo, Peirce se guardó muy bien de buscar códigos en todos lados manteniéndose fiel a la distinción entre los símbolos - que es lo que corresponde al uso de códigos en mensajes -, por un lado, y los índices y los iconos, por otro lado. Peirce no pretendió buscar códigos atrás de los signos icónicos y los signos indéxicos.

La idea del código la toma la semiótica de de Saussure; este fue quién, limitándose expresamente al lenguaje, desarrolló el análisis clásico que lleva a la semiótica generalizada a distinguir entre el léxico y la sintaxis no solamente en el lenguaje sino a tratar de encontrar sus análogos en los más diversos campos de los fenómenos culturales - por lo menos -. De Saussure tuvo el sentido de restringir su modelo únicamente al lenguaje, ${ }^{9}$ mientras que la semiótica tomó la ampliación peirceana del concepto de signo y le aplicó el modelo saussureano del lenguaje y, por tanto, se dio a la búsqueda infatigable del código en esferas de la realidad que no tienen nada que ver con los signos en términos de sentido común tradicional - y que, entonces, van más allá de los "símbolos" peirceanos para abarcar a los

\footnotetext{
${ }^{8}$ Véase: “Los sesentas y los setentas tempranos pueden ser vistos como la cúspide el 'imperialismo' semiótico, cuando la disciplina se anexó vastos territorios de los fenómenos culturales (...). En Una teoría de las semiótica, Eco (1976) definió el campo como incluyendo empresas tan diversas como la narratología (...), la zoosemiótica (el comportamiento comunicativo de las comunidades no humanas), la kinésica y la proxémica (códigos socioculturales que tienen que ver, respectivamente, con el movimiento humano la proximidad), la teoría de textos, alfabetos desconocidos, códigos secretos, códigos musicales, la semiótica médica y los signos olfatorios." (NV 21)

${ }^{9}$ Sin embargo, Metz se encarga de recordarnos que “(...) de Saussure también dio el fundamento para una ciencia (...) amplia, la semiótica, de la cual la lingüística no sería más que una rama (...)” (FL 60).
} 
eNweva Etinenaxia Revista Digital de OFilosofia ISSN 1850-3578 2013 - Vol. 8 - Número VIII - Resistencia, Chaco, Argentina. Pp. 58 - 90

"índices" y los "iconos" - ${ }^{10}$ Para clarificar esto conviene remitirse al ejemplo del lingüista de campo. $^{11}$

El lingüista de campo, equipado con la herencia sausurreana, se confronta típicamente con una masa en principio homogénea de eventos sonoros que él supone que son eventos lingüísticos - por ejemplo en el caso de un grupo humano recién descubierto en lo profundo de la selva amazónica - y entonces empieza un esfuerzo de análisis para encontrar las "unidades" que son las palabras del léxico y al mismo tiempo tratar de determinar las "reglas" de la "combinación" de dichas unidades, reglas que constituyen la gramática - y en especial la sintaxis - del lenguaje en cuestión. Con eso, el lingüista de campo determina científicamente el sistema ideal, que es el lenguaje cuyos eventos verbales él analiza, y que da "estructura", que "articula", todos los mensajes o "textos", es decir, dichos eventos verbales.

Por su parte, el semiólogo armado con la pretensión omniabarcante peirceana combinada con el modelo de la lingüística estructural saussureana se enfrenta, como el análogo del lingüista de campo, con un conjunto presupuestamente unitario de eventos culturales, que pueden ser culinarios, relativos al vestuario, al mobiliario, a las imágenes o los modales de mesa o de cortesía en general - o a lo que se desee -, conjunto de eventos que en su unidad es más o menos homogéneo, y entonces el semiólogo inicia un esfuerzo de análisis para determinar el código o los códigos correspondientes. La suposición atrás de esto es a) que todo es signo (Peirce) y b) que, además, a cada totalidad más o menos homogénea de eventos culturales corresponde un código que estructura dichos eventos - aunque, según se indicó, de Saussure limitó su modelo estructural al lenguaje - .

\section{La semiótica cinematográfica}

En lo anterior hemos simplificado la situación grandemente y no faltará el semiólogo que con toda razón señale que se cometió alguna inexactitud - a más de varias reducciones o simplificaciones para él inadmisibles -, no obstante, la esquematización realizada permite entender el carácter básico de las situación generada por la semiótica en tanto teoría que pretende dar cuenta de manera sistemática de nada menos que la totalidad de los fenómenos de la cultura - por lo menos - reduciéndolos a "mensajes" y "textos" o "comunicación" de acuerdo con el "lenguaje" correspondiente a un "código". La esquematización realizada nos permite en particular acercarnos a nuestro problema específico, es decir, el de la "semiótica cinematográfica" como propuesta teórica para dar cuenta de la inteligibilidad del cine

\footnotetext{
${ }^{10}$ Véase Metz: "Los post-saussurianos son más saussurianos que de Saussure mismo: están convirtiendo directamente la semiótica que él previó en una disciplina translingüística. Y esto es algo muy positivo." (FL 60)

${ }^{11}$ Para una exposición de la situación del lingüista de campo, véase el capítulo 2 de WO, de Quine.
} 
partiendo de que cada película es un "mensaje", "texto" o "discurso" que "significa" de acuerdo con un "sistema de lenguaje" estructurado por uno o varios "códigos". ${ }^{22} \mathrm{El}$ representante canónico de esta idea es Christian Metz, a cuyo examen pasamos ahora.

En la obra de Metz se encuentra por lo menos tres veces la idea expuesta en el siguiente pasaje tomado de su ensayo El cine: ¿un lenguaje o un sistema de lenguaje? (1964): ${ }^{13}$

“(...) el mensaje cinematográfico total pone en juego cinco niveles principales de codificación, cada uno de los cuales es un tipo de articulación: (1) la percepción misma (sistemas para la estructuración del espacio, 'figuras' y 'fondos", etc.), hasta el grado que esta constituye un sistema de inteligibilidad adquirida, la cual varía de acuerdo con las diferentes 'culturas'; (2) el reconocimiento y la identificación de objetos visuales y auditivos que aparecen en la pantalla, es decir, la habilidad (que también es adquirida culturalmente) para manipular correctamente el material denotado por el filme; (3) todos los 'simbolismos' y connotaciones de varias clases que se añaden ellas mismas a los objetos (o las relaciones entre objetos) fuera de los filmes, es decir, en la cultura; (4) todas las grandes estructuras narrativas (en el sentido de Claude Bremond) que dominan fuera de los filmes (pero también en ellos) en cada cultura y, finalmente, (5) el conjunto de sistemas propiamente cinematográficos que, en un tipo específico de discurso, organizan los diversos elementos formados para el espectador por las cuatro instancias precedentes." (LC 62, c. n.) $)^{14}$

Por supuesto, la teoría de Metz es amplia y reviste diferentes complejidades pero el párrafo anterior resume la idea básica de la misma. Los únicos términos del pasaje que no hemos considerado explícitamente hasta este momento son el de "articulación" y el de "discurso". Se trata de nociones básicas de la semiótica estructural en su recurso al concepto de código. Este, el código es en realidad un sistema integrado por los elementos que forman un "léxico" y que se "permutan" o "combinan" de acuerdo con ciertas reglas, que son la "sintaxis" correspondiente. El código así entendido es un sistema de "lenguaje" y cada permutación válida - gracias al cumplimiento de las reglas sintácticas - de elementos del léxico es un evento, una ocurrencia de un "texto" o "discurso" que ha sido posible gracias a su "articulación" o "estructuración" de acuerdo con el código. Así, los eventos sonoros con los que se enfrenta el lingüista de campo son eventos lingüísticos gracias a la correcta articulación

\footnotetext{
${ }^{12}$ Véase Metz: “(...) lo que llamaremos 'film' (...) es el filme en tanto discurso significante (texto) o en tanto objeto lingüístico (...)" (LC 13).

${ }^{13}$ En el mismo volumen véase FL 111-12, especialmente la nota de pie de página a FL 112,; véase también LC 33-4 y adicionalmente véase LC 269.

${ }^{14}$ Véase también FL 111, donde Metz insiste de una manera todavía más enérgica en que la percepción está codificada.
} 
sintáctica de los elementos del léxico correspondiente. En esta su "articulación" los eventos sonoros son no solamente eventos lingüísticos sino que se articulan en textos o discursos más o menos grandes mediante nuevas combinaciones sintácticamente válidas. Mencionemos brevemente que en el pasaje en cuestión aparece la noción de "inteligibilidad adquirida" y que corresponde exactamente a lo que nosotros llamamos arriba inteligibilidad artificial, códica, por oposición a la inteligibilidad natural que basa en la simple experiencia de cómo es el mundo, de cómo son las cosas. Esta experiencia es ganada en el simple decurso vital mientras que las inteligibilidades "adquiridas" provienen del aprendizaje especial del código. Uno aprende de manera natural que la sonrisa de la madre "expresa", "significa" alguna satisfacción, pero uno tiene que ser entrenado de manera especial para entender la declaración "estoy contenta" o I am happy o bien Ich bin froh, por ejemplo; comprender esas expresiones, saber su significado - este sí significado en sentido estricto - requiere del entrenamiento lingüístico correspondiente que no se reduce a la simplicidad de la mera experiencia vital. Queda, pues, claro que el "mensaje cinematográfico" tal como lo entiende Metz es una inteligibilidad adquirida, artificial, que exige el dominio de los códigos correspondientes, de, por lo menos, según Metz, cinco niveles o tipos de codificación. Podemos decir entonces que la hipótesis básica de las semiótica cinematográfica, en este caso representada por su teórico clásico Metz, es la de que el cine es una inteligibilidad artificial basada en el dominio de por lo menos cinco códigos que "articulan" cada film como un "mensaje total", como un "discurso" o "texto".

\section{Examen de los códigos de Metz}

Habrá que empezar señalando que tenemos muy serias dudas de que exista cada uno de los cinco niveles de codificación a los que hace referencia Metz, y esta sección está dedicada a formular nuestras objeciones a los primeros cuatro niveles de la supuesta codificación o articulación del pretendido "discurso cinematográfico". ${ }^{15} \mathrm{El}$ quinto nivel, el cual pretendidamente organiza los elementos "significantes" aportados por los cuatro niveles previos de codificación, merece un tratamiento aparte porque que según Metz sería el propiamente cinematográfico, mientras que los cuatro niveles previos serían más bien lo que correspondería a la semiótica de la cultura en sentido amplio (cfr. FL 111).

\subsection{Primer nivel códico}

Siguiendo a otros semióticos, Metz parte de que la percepción en realidad no es un fenómeno natural sino un fenómeno cultural y, más específicamente, de "significación" culturalmente

\footnotetext{
${ }^{15}$ Ciertamente se trata de "niveles de inteligibilidad" (FL 114), pero es muy dudoso que se trate de niveles de codificación, es decir, de inteligibilidad realmente artificial y no natural.
} 
determinada, lo que quiere decir, en términos de Metz, de "inteligibilidad adquirida" gracias a la sistematicidad de un código de la percepción. ${ }^{16}$ En su extremo, esta concepción implica que una escena dada corresponde idealmente a lo que sería la emisión de un mensaje - aunque dejemos de lado aquí quién es el emisor - y, por tanto, comunicaría un significado o muchos. Las diferentes maneras de percibir una escena serían entonces otros tantos eventos "discursivos" de un "lenguaje" perceptivo. Dejando de lado aquí también el que con esto se elimina la venerable distinción tradicional entre percepto y concepto, lo cierto es que las escenas quedan reducidas a posibilidades textuales de tal manera que su captación es la comprensión de un "texto" o un "discurso" Nótese la enorme consecuencia de la hipótesis de que la percepción está codificada: el mundo sensible queda reducido a textos, a discursos. Y la idea no es simplemente que la comprensión, la inteligibilidad del mundo necesite conceptos, no es simplemente que, como diría Kant, las "intuiciones" - los perceptos - sin conceptos sean ciegos - ininteligibles $-{ }^{17}$ sino que se trata de algo mucho más radical, a saber, de postular que toda conceptualización del mundo es parte de un código, el cual, como se dice en el pasaje citado, corresponde a una cultura. En otras palabras, la hipótesis de Metz lleva a concluir que no hay ninguna inteligibilidad natural del mundo sino que toda inteligibilidad es adquirida mediante el logro del dominio de un código - específico a una cultura -. Por supuesto, esto está muy en consonancia con los resultados postestructuralistas del estructuralismo de inspiración saussuriana, pero no nos interesa discutir esto ahora, sino solamente cuestionar la idea de que toda percepción se basa en códigos que serían "sistemas" especiales - "culturales" - de "organización del espacio".

Prescindiendo aquí de la muy amplia discusión de estos tópicos en el ambiente postmoderno actual, señalemos ahora simplemente que la distinción entre "figura" y "fondo" viene de la psicología de la percepción y se trata del planteamiento muy básico de que toda percepción humana, gracias a su eficiencia de origen evolutivo y, con ello, filogenético, está orientada a distinguir objetos separándolos como "figuras" contra un "fondo" ${ }^{18}$ Sin limitarnos aquí al caso de los humanos podemos suponer que, por ejemplo, también un perro es capaz de distinguir

\footnotetext{
${ }^{16}$ Véase: "Los códigos iconológico, perceptivo y otros códigos son culturales." (LC 113) O, de otra manera, "Julián Greimas (...) a subrayado la importancia del código lingüístico en el desciframiento de los objetos visuales. La vista (...) reconoce aquellas cosas para las que el lenguaje a proveído un nombre [substantivo]. Existe, para Greimas, una amplia correspondencia entre (...) los objetos reconocibles ópticamente, cada uno de los cuales es una clase de ocurrencias (...) y ciertos sememas de las lenguas naturales (...)” (LC 33). Véase la discusión de esto en la siguiente sección de nuestro texto.

${ }^{17}$ Se trata de uno de los pasajes más famosos de la Crítica de la razón pura: "Los pensamientos sin contenido [intuiciones] son vacíos, las intuiciones sin concepto son ciegas." (KrV B75)

${ }^{18}$ Fue Edgar Rubin, en la corriente gestaltiana, quien alrededor de 1915 empezó a utilizar el par de conceptos "figura" y "fondo" en su libro Figuras visuales.
} 
un objeto particular, como una liebre corriendo, contra el "fondo" de unos yerbajos o de los tallos de un trigal, y que también le resulta posible distinguir el olor particular del zorro como "figura" odorífica contra el fondo de una mezcla abigarrada de la amplísima multitud de olores de la campiña en tanto "fondo" igualmente odorífico.

Parece evidente que el perro gana, adquiere, estas habilidades de orientación en el mundo y, por lo tanto, cognitivas, que es capaz de entender los "significados" correspondientes, porque la distinción de "figuras" separándolas de un "fondo" es una capacidad natural realmente innata que adquieren muchos animales más o menos complejos, incluidos los humanos, con la simple maduración biológica, filogenética, es decir, propia de todos los integrantes de la especie correspondiente. Igualmente evidente parece ser que en esto está completamente ausente toda inteligibilidad adquirida en el sentido de la habilidad en el uso de un código, de la adquisición del mismo. Y si para la capacidad perceptivo intelectiva que le permite al perro orientarse en el mundo, distinguiendo un figura de un fondo, no se necesita ningún código, resulta necesario preguntarse si en realidad la percepción humana no funciona, en el nivel básico de la distinción de figuras contra fondos, como la del perro - a pesar de las diferencias correspondientes debido a que el hombre y el perro tienen distintos sistemas perceptivos en términos puramente biológicos -

Metz deja implícitos cuáles serían los otros "sistemas para la estructuración del espacio" distintos del muy básico que separa "figuras" de un "fondo", pero podemos suponer que se refiere a otros como el muy conocido de la importancia del centro de una escena respecto de sus bordes. En relación con este tipo "organización" que da importancias - "significados" diversas a diferentes zonas de espaciales, parece razonable suponer que esta importancia diferenciada no corresponde a un código que "articula" diferentes zonas espaciales de acuerdo con alguna regla sino, nuevamente a características filogenéticas de la percepción humana. En este caso, una escena es un todo en un espacio circunscrito, que es el análogo del campo visual, y como en el campo visual lo único que se percibe de manera nítida es lo que aparece en el centro, siempre resulta más importante, más "significativo" en términos de la orientación inmediata esto que se percibe claramente y que está, justamente, en el centro del campo visual. Así, el hombre vuelve la cabeza hacia lo que le llama la atención porque es la única manera de ponerlo en el centro del campo visual y, con ello, de percibirlo con nitidez, y como una escena se forma a partir del centro del campo visual extendiéndose hacia sus bordes, espacios más o menos circunscritos como lo que está encerrado entre ciertos elementos, por ejemplo paredes, requieren que lo más importante o llamativo en términos existenciales - sea lo que sea, digamos la figura de un dios - quede en la zona central de la región circunscrita por 
Pverea Etinexaxio Revista Digital de OFilosofla ISSN 1850-3578 2013 - Vol. 8 - Número VIII - Resistencia, Chaco, Argentina. Pp. 58 - 90

los elementos en cuestión. En otras palabras, la importancia del centro respecto de la periferia en todo espacio circunscrito es el análogo de la estructura de la visión humana y su utilidad cognitiva y no tiene nada que ver con la adquisición de ningún código propio de cultura alguna. Resulta fácil hacer razonamientos similares, que remiten a características de la especie humana y su adaptación al entorno, para explicar "organizaciones" espaciales en las que, por ejemplo, lo más atractivo en términos existenciales se ubica no solamente en el centro sino en la parte superior de un espacio determinado mientras que lo negativo en términos existenciales se ubica en la parte inferior del espacio en cuestión. La experiencia muestra que una multitud de cosas "negativas" se encuentra en regiones espaciales bajas mientras que cosas "positivas" como la luminosidad se encuentran o parecen provenir de las regiones espaciales superiores. Nuevamente una organización espacial con una valoración positiva del arriba y una negativa del abajo remite no a un código sino a la inteligibilidad natural dada por la experiencia de "cómo son las cosas en el mundo" - a partir de ello resulta simplemente natural que se tienda a colocar las estatuas de deidades sobre un pedestal ubicado en el centro de una pared o de algún recinto, por ejemplo -.

\subsection{Segundo nivel códico}

Como lo describe Metz, este nivel del "mensaje cinematográfico" conlleva la habilidad consistente en el reconocimiento de objetos perceptivos - visuales y auditivos - y, esto sería también un rasgo "adquirido culturalmente". Para empezar debe subrayarse que se trata de una habilidad específicamente conceptual con base perceptiva. En realidad, y para usar nuestra discusión anterior sobre las capacidades cognitivas caninas, parece plausible suponer que un perro es capaz de reconocer el objeto "gato" a pesar de sus múltiples variaciones perceptivas, de la misma manera en la que reconoce a otro perro como perro y no como, digamos, gato. En otras palabras, más allá de la distinción puramente sensorial de infinitas figuras posibles de un gato contra infinitos fondos posibles, el perro es capaz, además, de reconocer esas mismas múltiples "figuras" - a pesar de ser distintas - como instancias del tipo perro. ${ }^{19}$ Dado que los tipos son justamente los conceptos, ${ }^{20}$ al distinguir con precisión entre perros y gatos, se muestra que la inteligencia natural del perro realmente alcanza el nivel

\footnotetext{
${ }^{19}$ Recuérdese aquí el pasaje de Metz sobre Greimas ya citado en una nota de pie de página: "Existe, para Greimas, una amplia correspondencia entre (...) los objetos reconocibles ópticamente, cada uno de los cuales es una clase de ocurrencias (...) y ciertos sememas de las lenguas naturales (...)" (LC 33). Nótese la idea de Greimas - según nos la refiere Metz - de que un objeto, en realidad, su concepto, es "una clase de ocurrencias". Las "ocurrencias" son lo que nosotros llamamos instancias y la "clase" tal es lo que nosotros llamamos tipo.

${ }^{20}$ Sobre la relación exacta entre tipos y conceptos puede haber discusión, pero por lo menos están en cierta relación de implicación recíproca o equivalencia.
} 
Q Nueve Otinenaxio Revista Digital de Prilosofla ISSN 1850-3578 2013 - Vol. 8 - Número VIII - Resistencia, Chaco, Argentina. Pp. 58 - 90

conceptual, y esto a pesar de no tener ningún elemento de un léxico asociado al tipo gato, al tipo perro, etc. ${ }^{21}$ Así pues, dejando de lado prejuicios antropocéntricos muy arraigados pero cada vez más cuestionables, parece difícil rechazar que más allá de la distinción sensorial cognitiva entre figuras y fondos el perro hace distinciones cognitivas estrictamente conceptuales, que su capacidad cognitiva combina el uso de perceptos con el uso de conceptos, $^{22}$ y todo esto de manera totalmente natural. En otras palabras, no solamente no es necesario reducir la percepción de "figuras" contra "fondos" a un "sistema" "cultural" de la "organización del espacio", sino que incluso los estados mentales perrunos que corresponden a los tipos, es decir, a conceptos, ${ }^{23}$ que agrupan las diferentes instancias en toda una clase de perceptos, son conceptos naturales sin elemento léxico alguno que les corresponda, son estados mentales no solamente preverbales sino, en este caso, averbales - ya que los perros no parecen tener léxico alguno $-{ }^{24}$

Nótese que si no desligamos el concepto, en tanto capacidad de reconocer instancias de un mismo tipo, de la supuesta necesidad de que el concepto corresponda a una palabra de un léxico, no hay forma razonable de explicar cómo es que el perro puede reconocer perros y

\footnotetext{
${ }^{21}$ Recuérdese aquí nuevamente el pasaje de Metz sobre Greimas ya citado en notas de pie de página: "Existe, para Greimas, una amplia correspondencia entre (...) los objetos reconocibles ópticamente, cada uno de los cuales es una clase de ocurrencias (...) y ciertos sememas de las lenguas naturales (...)" (LC 33). Nosotros también reconocemos, en el caso de los humanos, una correspondencia entre elementos lingüísticos y la "clase de ocurrencias" - el tipo o concepto - pero creemos que simplemente la cognición animal parece evidenciar que el reconocimiento de la ocurrencia como ocurrencia - instancia - de una clase - un tipo - no requiere de sememas, los cuales, por lo demás, se conciben en la lingüística estructural como elementos definidos por oposiciones lingüísticas - dicho aquí de manera simplificada - y no en relación con las ocurrencias que son su referente.

${ }^{22}$ Como lo requería Kant en su definición clásica del conocimiento en tanto capacidad que consta de "dos partes", la intuición o sensibilidad sensorial y el concepto o entendimiento. Esto se encuentra justamente antes de la famosa frase kantiana ya referida arriba - en nota de pie de página - en el sentido de que los conceptos sin intuición (sensación) son vacíos y las intuiciones sin concepto son ciegas (cfr KrV B75).

${ }^{23}$ Acerca de los conceptos como estados mentales véase, por ejemplo, de Dretske, NM, capítulo 1.

${ }^{24}$ Véase nuevamente la nota en la que se cita un pasaje de Metz en el que refiriéndose a Greimas dice que "[I]a vista (...) reconoce aquellas cosas para las que el lenguaje a proveído un nombre." (LC33) La situación es exactamente a la inversa, por lo menos en el nivel de reconocimiento muy básico que se suele llamar el de las "clases naturales". Los humanos y los perros reconocemos algunas de las mismas cosas pero los perros no tienen ningún nombre para ellas - aunque pueden aprender nombres hasta para unas doscientas cosas, según muestran los experimentos sobe inteligencia animal -. Metz continua el pasaje recién citado diciendo que "[e]xiste, para Greimas, una amplia correspondencia entre (...) los objetos reconocibles óptimamente, cada uno de los cuales es una clase de ocurrencias (...) y ciertos sememas de las lenguas naturales (...)" (LC 33), lo cual es correcto, solamente que hay que invertir el orden de fundamentación cognitiva: primero están los reconocimientos - los tipos - y luego vienen los "sememas" en diferentes lenguas, distintos para los mismos tipos. Por supuesto, la lingüística estructural, con su desatención al referente de los nombres y su definición básicamente a partir de las mera oposiciones o diferencias dentro de una "clase paradigmática", no puede reconocer esa situación. Para ella no es el objeto de referencia, de hecho este no le interesa, el que determina el significado del nombre, sino la relación entre nombres en el mismo "paradigma".
} 
gatos y distinguir unos de otros. La alternativa de decir que a) el perro tiene un "léxico" puramente mental sin ninguna correspondencia sonora, y b) que este léxico es un código en el sentido propio de una estructura de "inteligibilidad adquirida", artificial, no natural, parece descabellada. No sería razonable, pues, sostener que el conjunto de tipos de instancias que un perro es capaz de reconocer, constituye un código que genera una "inteligibilidad adquirida" y, además, "culturalmente", porque eso implicaría la existencia de un lenguaje puramente interno, no sonoro y no comunicativo, del perro.

$\mathrm{Si}$, por otra parte, el hombre es capaz de tener los mismos logros perceptivo intelectivos del perro consistentes en distinguir objetos como figuras contra fondos $y$, adicionalmente, categorizar a múltiples figuras como instancias del mismo tipo, es decir, de reconocer objetos de una clase y por tanto de utilizar conceptos, entonces, no parece existir ninguna razón para decir que el hombre lo hace con base en que pose elementos léxicos en el sentido propiamente lingüístico de elementos de un código verbal. ${ }^{25}$ Claro que podría ser así, pero no se ve ninguna necesidad de postular que un hombre hace lo mismo que un perro gracias a que posee un lenguaje en el sentido estricto de un código verbal. Queda claro, entonces, que no resulta razonable sostener la muy sofisticada hipótesis de que el hombre percibe y reconoce gracias a una "inteligibilidad adquirida" en tanto "sistema de organización el espacio" de origen "cultural" a partir de "figuras" y "fondos" y que, además, sus conceptos básicos de origen perceptivo son parte de un código. Aplicando la regla de la recurrir a la explicación más plausible, ${ }^{26}$ podemos descartar sin problema la idea de la existencia de un código perceptivo y por tanto del carácter léxico de la percepción. Las escenas tienen una inteligibilidad básica perceptos asociados a conceptos - que aun cuando pueda ser expresada mediante una descripción verbal en alguno de los idiomas de la Babel lingüística, no depende de la existencia de ningún lenguaje, sino que es una inteligibilidad natural, absolutamente al margen de todo código y precódica, en particular, preverbal.

En tanto natural, la inteligibilidad básica asociada con la percepción no tiene carácter cultural, es transcultural, de hecho, aunque esto sea materia de una discusión mucho más amplia, tal inteligibilidad es transhumana, válida de la misma manera para toda inteligencia que se asocie con perceptos que perciban lo mismo que los humanos aunque dichos perceptos sean qualia diferentes. Los qualia humanos y caninos que corresponden a instancias de gato o de perro, son diferentes formas de experimentar los mismos objetos, a saber, los perros y los gatos, es

\footnotetext{
${ }^{25}$ Que es lo que según vimos hacen Metz y Greimas con su referencia a los "sememas" - para no mencionar a muchísimos otros autores que sostienen la misma idea - según vimos en la cita de LC 33.

${ }^{26}$ Se trata de la famosa regla de la inference to the best explanation (IB 184 - 193).
} 
Q Nueva Etinexaxio Revista Digital de OFilosofia ISSN 1850-3578 2013 - Vol. 8 - Número VIII - Resistencia, Chaco, Argentina. Pp. 58 - 90

decir, en cuanto a gatos y perros, humanos y perros distinguen los mismos objetos de diferente manera - con diferentes sistemas sensoriales - pero los entienden como instancias de los mismos tipos. Con diferentes experiencias, entendidas como sensaciones, los perros y los hombres entienden, saben, cuando lo que ven, lo que experimentan, la instancia con la que se confrontan, es un perro o bien un gato, y para esto no necesitan de ningún código o inteligibilidad adquirida en una cultura, más bien, hay un nivel de inteligibilidad natural, que no solamente no es cultural sino que es transhumana, de hecho, es tanto subhumana como suprahumana, porque no solamente los perros sino también una especie humanoide superior a nosotros - para la cual nosotros seríamos lo que los neandertales fueron para los cromañones - seguiría distinguiendo a sus propios perceptos de perros y gatos como instancias del tipo perro y del tipo gato, y todo esto independientemente de que tuvieran o no algún lenguaje. La variabilidad de los códigos lingüísticos no afecta lo que el mundo es, cómo son las cosas en su nivel más básico. Independientemente de lo que cualquier cultura pueda pensar del sol o de la luna, nunca los va a confundir entre ellos ni con un perro ni con un árbol. ${ }^{27}$ En síntesis, el reconocimiento de objetos con base perceptiva directa es preverbal e independiente de todo código.

\subsection{Tercer nivel códico}

Se trataría en este caso de los simbolismos y connotaciones que se añaden a los objetos "en la cultura", por supuesto, en una cultura dada. Si se considera el nivel códico anterior se verá que ahí Metz habla del "material denotado por el filme", es decir, de las cosas u objetos que reconocemos directamente en los planos fílmicos. El presente nivel códico incluye la connotación, es decir, aquello que dichos objetos mismos "significarían" - aparte de sí mismos -, de acuerdo con una cultura, por ejemplo, un león puede "significar" grandeza, valor, etc. La imagen del león en el film "denota" - "significa literalmente" - un león real, y esta "denotación", el león mismo, puede "significar", digamos, grandeza, la cual sería, entonces, la “connotación” o la "significación connotativa” de la imagen del león. Al "denotar" al león, la imagen "connota" la grandeza. Es posible interpretar este proceso, según este ejemplo, aplicando el concepto tradicional de alegoría, y debe notarse que las alegorías se aceptan porque se comprenden. Es decir, no se trata de una simbolización meramente arbitraria ${ }^{28}$ que

\footnotetext{
${ }^{27}$ De hecho, estamos obligados a suponer que tanto los neandertales como los cromañones distinguían perfectamente, digamos, a los mamuts, y los entendían como instancias - "ocurrencias" diría Greimas del mismo tipo, es decir, que tenían el mismo concepto para el reconocimiento del animal en cuestión, independientemente de lo que hablaran o cómo hablaran ambas especies humanoides, incluso de si en un momento dado hablaban o no.

${ }^{28}$ Esto es lo que Metz llama "arbitrariedad total” (FL 110).
} 
se acepta por costumbre - como suele ser el caso del logotipo comercial -, sino que remite a cierta inteligibilidad natural. Así, resulta "natural" con base en la experiencia general del mundo y en propiedades perceptivas de los objetos león y hiena, que se asocie al león con la grandeza pero no a la hiena, a la paloma con la paz pero no al alacrán.

Ocurre también que muchas alegorías pueden ser concebidas como cercanas a las metáforas, es decir, la verbalización de la alegoría no verbal se aproxima a una metáfora, como cuando se dice que "el león es la grandeza" o "el valor". Y al igual que las metáforas propiamente dichas, como la de que "Aquiles es un león", las alegorías, verbales o no, también tienen que ser aceptadas. Si alegorías y metáforas se aceptan, produciendo placer y sorpresa, y no simplemente se convienen sin más, es porque son un tipo de inteligibilidades naturales que difieren completamente de las inteligibilidades adquiridas - artificiales - de los códigos. En su naturalidad, las simbolizaciones alegóricas y metafóricas adquieren la apariencia de asociaciones habituales de ideas, lo cual hace perder de vista con facilidad su carácter de inteligibilidades naturales. Hay que insistir en que símbolos alegóricos así como alegorías verbales y metáforas tienen una base natural trasnlingüística y transcultural que remite a "cómo son las cosas". ${ }^{29}$ Dicha naturalidad queda resaltada cuando se compara a las alegorías y a las metáforas con simbolizaciones totalmente arbitrarias del tipo que suelen ser muchos logotipos.

Ahora bien, separando de la tradición retórica el concepto de connotación, lo cierto es que en la semiótica se ha desarrollado dicho concepto para referirse a lo que simplemente podríamos llamar aquí asociaciones de ideas de carácter habitual en un grupo humano dado. Es evidente que en el seno de una cultura es común asociar ciertas ideas con los objetos conocidos por esa cultura, así sean objetos imaginarios, como un dragón o un unicornio. Sin embargo no queda claro que sea posible considerar a los objetos - reales e imaginarios - conocidos por una cultura como unidades léxicas, y es todavía menos claro que se pueda afirmar que haya reglas para combinar estos objetos en tanto "denotaciones" culturales de manera tal que dichas combinaciones arrojen a su vez "connotaciones" propias de una cultura. En general, la utilidad

\footnotetext{
${ }^{29}$ Toda persona, independientemente de la cultura, que esté informada sobre Aquiles y los leones entiende sin problema la famosa metáfora "Aquiles es un león". Cuando se dice que la metáfora es relativa a la cultura simplemente se confunde el acceso al contexto de una información, con una manera contextual de acceso a la información. La comprensión de las metáforas requiere información sobre los términos que aparecen en la metáfora, y esa información puede depender de la cultura - en culturas donde no se sabe nada de los leones, la metáfora no se puede entender aunque es sepa que Aquiles era un bravo guerrero - pero la comprensión de la metáfora una vez que se tiene la información necesaria no depende de la cultura. Lo que se necesita para entender una metáfora - y muchas otras cosas - es solamente el acceso al contexto de la información. Por eso no se necesita ni ser griego arcaico ni tampoco occidental en general, para entender la famosa metáfora homérica.
} 


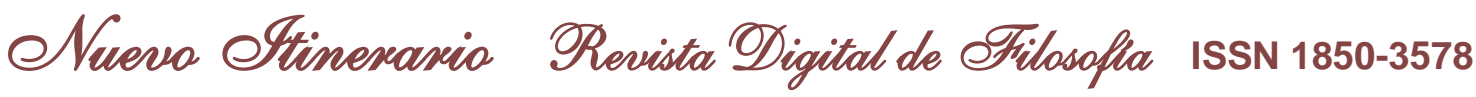
2013 - Vol. 8 - Número VIII - Resistencia, Chaco, Argentina. Pp. 58 - 90

del concepto de "connotación" parece no alcanzar hasta la aplicación del concepto de "código" para considerar la inteligibilidad de las "connotaciones".

Por otra parte, si se deja de lado a Peirce, para quien "símbolo" es una unidad significante que es parte del léxico de un código o una combinación sintácticamente correcta de dichas unidades, en la semiótica es común mantener en una cercanía difusa las nociones de "símbolo" y "connotación", como ocurre en el pasaje de Metz que estamos sometiendo a escrutinio. Sin embargo, existe por lo menos un concepto de símbolo que puede ser distinguido del concepto de "connotación", a saber, se trataría de una asociación de ideas no habitual sino circunstancial, hecha posible por un contexto singular, en principio irrepetible, así, Metz se refiere a la imagen fílmica de un león que se levanta como símbolo del alzamiento proletario (cfr. FL 37). ${ }^{30}$ Queda claro que para simbolismos como asociaciones de ideas en contextos singulares, resulta aun menos razonable aplicar una noción de código en sentido estricto. Simples asociaciones de ideas, ya sean habituales o circunstanciales son algo muy diferente a la "articulación" de elementos léxicos propia de un código.

Por otra parte, hay lo que se podría llamar simbolismos muy bien definidos, como por ejemplo la cruz en tanto símbolo de la cristiandad y la media luna como símbolo de la fe musulmana, lo mismo que muchos logotipos comerciales. Símbolos de este tipo también son asociaciones de ideas y ciertamente son adquiridas. Uno puede simplemente aprender a asociar la cruz con todo lo cristiano, que la cruz remite a ello, sin necesidad de tener ni la más remota idea de la historia de la crucifixión como motivación para el uso de la cruz. Pero el conjunto de dichas asociaciones en una cultura es un todo amorfo que, nuevamente, está lejos del estatuto estricto de un código. A lo más que llegan es a ser asociaciones de ideas con base meramente convencional.

Queda claro, pues, que simbolismos y connotaciones culturales de todo tipo pueden ser reproducidas en los filmes pero están muy lejos de constituir codificación alguna. Si se debilita la noción estricta de código a la simple convencionalidad o arbitrariedad de la relación entre signos más o menos aislados y su denotación, entonces podemos decir que un cierto conjunto de símbolos forman un código, pero ni siquiera se puede decir esto de alegorías y metáforas ya que estás son aceptadas y si son aceptadas es porque en su base hay un núcleo bien definido de inteligibilidad natural.

\subsection{Cuarto nivel códico}

\footnotetext{
${ }^{30}$ Este es un ejemplo de la idea de Metz de que un objeto adquiere "solamente en el films (...) significaciones simbólicas que se derivarán de su localización en el discurso cinematográfico propiamente dicho." (FL 113)
} 


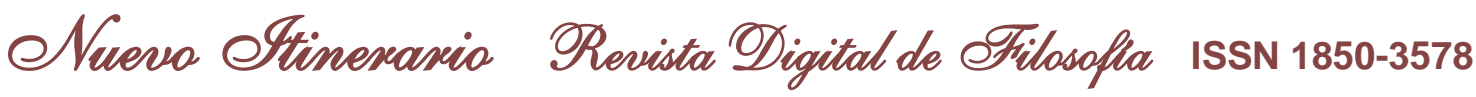
2013 - Vol. 8 - Número VIII - Resistencia, Chaco, Argentina. Pp. 58 - 90

Las "grandes estructuras narrativas" "en el sentido de Bremond" refieren a la idea básica de este autor de que "(...) es posible trazar a priori la red integral de elecciones factibles (...)" (AE 108) para la articulación de un relato o a la idea, en palabras del propio Bremond, de que es posible “(...) encadenar devenires en un relato a la vez imprevisible (por el juego de las combinaciones disponibles) y codificable (gracias a las propiedades estables y al número finito de elementos combinados)." ( AE 108) En los pasajes recién citados aparece con toda claridad la noción de las posibles combinaciones de un número finito de elementos, lo que es propio cualquier código en sentido estricto del término, en particular de los lenguajes, claro, bajo la aplicación de ciertas reglas de combinación de los elementos del léxico, de las reglas que forman una sintaxis. En este contexto resulta muy instructivo referir a Barthes quien de manera explícita establece una conexión - una "homología" - entre la idea la estructura de los relatos y la estructura de un lenguaje.

En su texto Introducción al análisis estructural de los relatos (1966) Barthes nos dice que “(...) nadie puede combinar (producir) un relato sin referirse a un sistema implícito de unidades y de reglas." (AR 4) Las "unidades" y las "reglas" remiten a la "estructura del relato" (AR 4), de hecho, esta estructura no es otra cosa que un código, por ello el “(...) 'arte del narrador (...) es poder crear relatos (mensajes) a partir de la estructura (del código) (...)" (AR 4, nota), y un poco más adelante Barthes hace explícito que el modelo para esta hipótesis del código del relato es justamente el lenguaje tal como lo trata la lingüística estructural: "En el estado actual de la investigación, parece razonable tener a la lingüística misma como modelo fundador del análisis estructural del relato." (AR 5) De hecho Barthes propone la idea de que existe una "lengua del relato" (AR 6), lo cual, es equivalente a postular que existe un código del relato. Según Barthes, “(...) es evidente que el discurso mismo (como conjunto de frases) está organizado y que por esta organización aparece como el mensaje de otra lengua, superior a la lengua de los lingüistas (...)" (AR 6). Nótese que una lengua es, por ejemplo el alemán, o el castellano, y dada cualquier lengua es posible hacer un relato en ella, y entonces, siguiendo la idea de Barthes, un relato, independientemente del lenguaje en el que esté escrito, es una expresión, un "mensaje" de "otra lengua", una lengua "superior", la cual sería, justamente, la “lengua del relato” en general. Así, “(....) el discurso tiene sus unidades, sus reglas, su 'gramática' (...)" (AR 6), por ello, el relato o “(...) discurso debe ser naturalmente objeto de una segunda lingüística (....)" (AR 6), a saber, la "lingüística del discurso" (AR 6).

Según Barthes la relación entre la lingüística en el sentido propio y la "lingüística del discurso" o relato es "homológica" (AR 8), más aún, "[I]a homología que se sugiere (...) implica una identidad entre el lenguaje y la literatura (...)” (AR 8), así, “(...) el lenguaje acompaña (...) al 
Q Nueva Etinexaxio Revista Digital de OFilosofia ISSN 1850-3578 2013 - Vol. 8 - Número VIII - Resistencia, Chaco, Argentina. Pp. 58 - 90

discurso, tendiéndole el espejo de su propia estructura (...)” (AR 8), la idea sería, pues, que “(...) la literatura (...) hace un lenguaje de la condiciones mismas del lenguaje (...)" (AR 8s). Queda clara entonces la noción de que la literatura es un "homólogo" de la lengua, una supralengua que tiene su propio código y así como el lingüista de campo se dedica a analizar eventos verbales en una lengua dada para encontrar el léxico y la sintaxis correspondiente, el narratólogo se dedica al análisis de eventos literarios, de relatos, para encontrar el código del relato en general.

Prima facie la idea de una "lingüística del relato" podría resultar plausible, pero tal plausibilidad se debilita ya por el simple hecho que los propios narratólogos Bremond y Barthes reconocen una correspondencia entre la literatura y la existencia, por lo que la tesis de que hay una lengua del relato conlleva la idea de que la vida misma, la existencia sería una "lengua, es decir, más allá de la "homología" entre lenguaje y la literatura, habría una homología entre las posibilidades de desarrollo de un relato y las de la vida misma. Así, Bremond nos dice que

"[e]ste engendrarse de los tipos narrativos es al mismo tiempo una estructuración de las conductas humanas activas o pasivas. (...) Cuando el hombre en la experiencia real, combina un plan, explora imaginativamente los desarrollos posibles de una situación, reflexiona sobre la marcha de la acción iniciada, rememora las fases del acontecimiento pasado, se cuenta a sí mismo los primeros relatos (...)" (AE 108s.).

Con ello la idea de que hay la supralengua que da la estructura de la literatura deviene ipso facto en la idea de que tal supralengua es al mismo tiempo la lengua de la existencia, lo cual concuerda con el hecho de que Barthes haga suya la tesis de J. P. Fayé de que "la ficción (o el relato) (...) siempre es (...) una experimentación del 'pensamiento' sobre la 'vida' (...)" (AR 50, nota de pie de página), por lo que no debe extrañar que "(...) el relato est[é] ahí, como la vida." (AR 3) La idea de que existe un código del relato equivale, entonces, a que existe un código de la existencia, de que la existencia es una "lengua", tesis que resulta por lo menos extraña. Sin embargo, parece claro que Metz abraza dicha idea porque en el numeral 4 de su recuento del los niveles de codificación en el filme nos dice que las “(...) estructuras narrativas (...) dominan fuera de los filmes (...) en cada cultura (...)" (FL 62). Resulta claro, pues, que Metz acepta la idea de la "sintaxis narrativa" (AR 24) de Barthes, y con ella la idea de la existencia de un código de los relatos que es "homólogo" a un código que "articula" la existencia verdadera, que le da su "estructura" a esta.

Por nuestra parte preferimos la hipótesis de que la "lógica de las acciones" (AR 11) en la narración y en la vida misma no corresponde a ningún conjunto "codificable" de 
Pverea Etinexaxio Revista Digital de OFilosofla ISSN 1850-3578 2013 - Vol. 8 - Número VIII - Resistencia, Chaco, Argentina. Pp. 58 - 90

"combinaciones" de un cierto "número finito" de "elementos", según una supralengua de la literatura y de la vida, sino que en ambos, en los relatos y en la vida, priva una inteligibilidad natural, la cual no tiene que ver con alguna "inteligibilidad" adquirida propia de la sistematicidad de un código. En el caso de cada relato la lógica de las acciones es construida por el narrador emulando la lógica de la conducta humana según la experiencia que se tiene de ella, dicho de otra manera, en la ficción del relato se emulan posibles situaciones de inteligibilidad reales que, básicamente, implican la creación de condiciones inferenciales. El lector anticipa posibilidades de las acciones con base en la experiencia vital y no por la aplicación de reglas de combinación a ciertos elementos. La idea de condiciones o situaciones de inferencia como forma específica de inteligibilidad natural tanto en la vida como en la literatura la discutiremos en la sección subsiguiente.

\section{Determinación del quinto nivel códico}

Al final del pasaje de Metz que estamos considerando, nuestro autor se refiere a "sistemas propiamente cinematográficos" que generan un "tipo específico de discurso", a saber, el "discurso fílmico" (FL 58). En otro texto, dos años posterior al texto del que tomamos el pasaje objeto de nuestra consideración, Algunos aspectos en la semiótica del cine (1966), Metz aborda nuevamente el tema del "mensaje fílmico" (FL 92), y en este texto Metz señala explícitamente "figuras básicas de la semiótica del cine" (FL 94), a saber, "el montaje, ${ }^{31}$ los movimientos de cámara, la escala de los planos las relaciones entre la imagen y el habla, las secuencias" (FL 94). Un tanto más específicamente se señalan los siguientes como "procedimientos del lenguaje fílmico: el acercamiento extremo [close-up], el giro de cámara [panning], el seguimiento [tracking], el montaje entrelazado o alterno - entre las primitivas fílmicas" (FL 95), que habrían sido "estabilizadas, es decir, codificadas" (FL 95) cada una como “categoría sintagmática" (FL 95), es decir, como tipo sintáctico de unidad léxica para ser combinada con otras o bien como regla sintáctica de combinación de unidades. En otras palabras, es en referencia a las "figuras" o "procedimientos" señalados - que constituirían un “cuerpo de procedimientos generadores de significado" (FL 95) - que habría que ubicar el nivel códico específicamente cinematográfico, al que se refiere el párrafo de Metz citado al inicio de esta sección de nuestro trabajo, porque dichas "figuras" forman parte de los recursos propiamente narrativos del cine (FL 95 s.). Justamente, según Metz, es en relación con la narratividad que también deben ser considerados "procedimientos" tales como la "disolución

\footnotetext{
${ }^{31}$ Véase el estatuto del montaje: "el montaje como estructuración de una coherencia inteligible por medio de varias conjunciones" (FL 134).
} 
y el la apertura de negro [fade-in ${ }^{32}$ ] y el giro de cámara" (FL 95). Todos los procedimientos antes mencionados los habría desarrollado el cine, nada más ni nada menos, “(...) en la medida en la que se confrontó con los problemas de la narración (....)" (FL 95), es decir, se trata de todo un "cuerpo de procedimientos significantes específicos" (FL 95) orientado a hacer del cine una "máquina para contar historias" (FL 92), de procedimientos que “(...) son de hecho narrativa fílmica." (FL 96). Y debe insistirse aquí en que la "estabilidad", la habitualidad de los mismos es lo que les confiere carácter códico. ${ }^{33}$

Ahora bien, existen otros elementos fílmicos, como la iluminación o variaciones mayores o menores en el "punto de vista" de la cámara sobre un sujeto dado, (cfr. FL 98), los "efectos fotográficos" (FL 98) u "ópticos" (FL 113), que aunque también generan "significado" - como "connotación" (FL 96 s.) -, son más bien parte de la "expresividad cinematográfica". En otras palabras una variación de la iluminación o del ángulo de la toma es capaz de crear una "impresión diferente" (FL 97), pero no contribuyen en nada a la inteligibilidad de la trama, es decir, de la narración; no tienen nada que ver con el "recital de los hechos" (FL 98) "contados" por la película en cuestión. En otras palabras, si lo que interesa es el cine como narración, la cual necesariamente incluye una secuencia de hechos, entonces la pregunta que interesa es la de “(...) cómo es que el cine indica sucesión, precedencia, saltos temporales, causalidad, relaciones adversativas, consecuencia, proximidad espacial o distancia, etc. (...) Estos son los problemas centrales de la semiótica del cine." (FL 98)

Entre los "procedimientos" para indicar, por ejemplo, sucesión están en ocasiones la disolución, la apertura de negro y el giro de cámara, ya mencionados. Así, una disolución y también un seguimiento suelen indicar el término de una situación, mientras que la apertura de negro, indica el comienzo de otra. De la misma manera, el acercamiento extremo resalta algún elemento causal o consecuente - un "actante" podrían decir los semióticos - de una cadena de hechos.

Sin embargo, las tres "primitivas" de la "significación" específicamente cinematográfica recién mencionadas son en principio planos fílmicos aislados, es decir, aunque diseñados para formar parte de alguna secuencia, en sí mismos, como cualquier otro plano aislado, no son montaje. Sin embargo, el "procedimiento" que caracteriza definitivamente al cine narrativo es el

\footnotetext{
${ }^{32}$ En castellano fade-in se traduce como "abrir de negro", que consiste en que de un punto en el que no se ve nada algo empieza a aparecer en la pantalla progresivamente.

${ }^{33}$ Véase: “(...) hay ciertos 'procedimientos sintácticos' que, después de un uso frecuente como habla, vienen a aparecer en películas posteriores como un sistema de lenguaje: se han convertido en convencionales hasta cierto grado." (FL 41)
} 
montaje como secuencia de planos. ${ }^{34}$ Por ello, nos dice Metz, “(...) el arreglo de [las] imágenes en una secuencia inteligible - (...) el montaje - nos transporta al corazón de la dimensión semiológica del cine (...)" (FL 101), lo cual resulta natural dado que el montaje en tanto arreglo secuencial de planos es el que lleva la carga principal en cuanto a "(...) indica[r] sucesión, precedencia, saltos temporales, causalidad, relaciones adversativas, consecuencia, proximidad espacial o distancia, etc." En otras palabras, el montaje es el principal elemento de "inteligibilidad fílmica" (FL 99) respecto del cine visto como "discurso narrativo" (FL 95) - y no como experiencia sensorial.$-^{35}$

La idea es que la "inteligibilidad fílmica" se basa en "un cierto número de hábitos dominantes" (FL 99) para la "articulación fílmica" (FL 99) de los planos o imágenes, ya que "[u]na película compuesta de manera azarosa no sería comprensible." (FL 99) Lo interesante aquí es la idea de que existe - porque en el desarrollo histórico del cine se llega a ellas - un conjunto de estructuras convencionales o reglas del montaje - "procedimientos sintácticos" (FL 41) - que garantizan la inteligibilidad fílmica:

"Mientras que una imagen nunca se parece completamente a otra, la gran mayoría de los filmes narrativos se parecen unos a otros en sus estructuras sintagmáticas. La narratividad fílmica (...), al hacerse estable a través de la convención y de la repetición en innumerables películas, gradualmente se ha configurado en formas que son más o menos fijas (...)" (FL 101). La noción de lo "sintagmático", del "sintagma", procede de la lingüística estructural de herencia saussuriana y es el nombre técnico para las combinaciones de unidades del léxico de acuerdo con las reglas de la sintaxis correspondiente, de manera tal que un fragmento de un discurso y el discurso mismo son "sintagmas" y deben ser entendidos como estructuras significantes, es decir, generadoras de inteligibilidad adquirida, convencional. Transponiendo la idea al cine, resulta que las formas "habituales" del montaje serían "convencionales" y "repetitivas", y cada una de ellas una forma de "sintagma fílmico" (FL 102). ${ }^{36}$ Queda claro, pues, que de los "procedimientos fílmicos" en general hay que separar específicamente los

\footnotetext{
${ }^{34}$ Véase: “(...) una película está compuesta de muchas fotografías (el concepto de montaje ...)” (FL 98), o bien: "Una película está hecha de muchas imágenes que derivan su significado en la relación de unas a las otras en una interacción completa de implicaciones recíprocas, símbolos, elipses, etc." (FL 43) Como era de esperarse, las "unidades significantes" (FL 115) en el cine "(...) son los 'planos'." (FL 115) Estos son "unidades discretas identificables en el discurso filmico" (FL 115), o también: "El plano es una (...) unidad, una unidad del discurso." (FL 116).

${ }^{35}$ Véase: "El dominio del 'relato' es tan poderoso que la imagen, de la que se dice que es el principal constituyente fímico, desaparece detrás de la trama que ha tejido (...), de tal manera que el cine es el arte de la imágenes solamente en la teoría." (FL 45)

${ }^{36}$ Véase: “(...) la secuencia fílmica es una unidad real - es decir, una suerte de sintagma coherente (...)” (FL 115), además: "los sintagmas (segmentos autónomos compuestos de varios planos)" (FL 125), es decir, se trata de estructuras significantes como tales estructuras.
} 


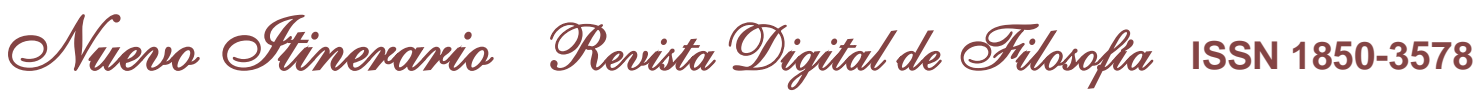
2013 - Vol. 8 - Número VIII - Resistencia, Chaco, Argentina. Pp. 58 - 90

"procedimientos sintácticos" o "sintagmáticos". Todos ellos se encuentras como formas del montaje y son aquello a lo que Metz se refiere propiamente como el quinto nivel del codificación fílmica.

De acuerdo con lo anterior resulta lógico que Metz remita a la idea de la "sintaxis cinematográfica" (FL 120) y a la necesidad de confeccionar "una lista de los ordenamientos principales de imágenes en las películas" (FL 121), lista que sería "una primera 'tabulación' de los componentes sintagmáticos de las películas" (FL 121). A continuación Metz señala que (hasta mayo de 1966) él distinguió "seis tipos principales, el plano autónomo, la escena, la secuencia, el sintagma descriptivo, el sintagma alternante (...) y el sintagma frecuentativo (...)" (FL 121). Un año después, sin embargo, la tabla sufrió algunos cambios y pasó a distinguir "ocho tipos principales de segmentos autónomos, es decir, 'secuencias' (...)" (FL 123), o sea, "ocho tipos sintagmáticos" (FL 124), que serían lo que realmente constituiría el quinto nivel de codificación, del "mensaje cinematográfico total” (FL 62) que es el específicamente fílmico.

\section{Examen crítico del quinto nivel códico}

Ahora bien, la tesis de Metz es doble, por una parte, que las estructuras sintagmáticas consignadas en tales tablas son forma de articulación de los planos que garantizan su inteligibilidad en términos narrativos, es decir, del desarrollo de un relato o historia; por otra parte, la tesis de Metz es que tales articulaciones son formas "estable[s] a través de la convención y de la repetición en innumerables películas" (FL 101) y que de ahí es de donde proviene su inteligibilidad, es decir, al igual que en el caso lingüístico propiamente dicho, la inteligibilidad del "sintagma" no es natural sino "adquirida".

Nuestra tesis crítica es que la inteligibilidad de las formas del montaje de los planos - en términos semióticos: las "articulaciones" y "ordenamientos" de los "significantes fílmicos" elementales - procede de un tipo especial de inteligibilidad natural, a saber, la inferencia. En otras palabras, el montaje genera situaciones de inferencia que en principio son iguales a cualesquiera otras, en particular, tales situaciones de inferencia fílmicas no difieren en tanto tales de las que se construyen en la literatura mediante palabras. Aquello que Barthes cree que es una "lengua del relato", según vimos arriba, no pasa de ser la descripción de situaciones ficticias o reales que permiten al lector $\mathrm{u}$ oyente hacer inferencias a partir de las situaciones que se le cuentan; de la misma manera, las formas del montaje o, en términos de Metz, "sintagmas fílmicos", no tienen nada que ver con estructuras estables y convencionales de inteligibilidad sino que se trata de la emulación de experiencias por medio de imágenes, emulación con base en la cual un observador puede hacer inferencias como si fuera testigo directo, observador, de esas situaciones. Nuestra aproximación al fenómeno de la 
eNweva Etinenaxia Revista Digital de OFilosofia ISSN 1850-3578 2013 - Vol. 8 - Número VIII - Resistencia, Chaco, Argentina. Pp. 58 - 90

inteligibilidad fílmica tiene, pues, un carácter que podría ser llamado cognitivista y que es muy diferente de la aproximación semiótica. La comprensión de un filme depende abrumadoramente de capacidades de intelección natural y en particular inferencial por parte del observador y no de una inteligibilidad artificial adquirida con base en una estabilización de formas proveniente de la convención y la repetición.

Para mostrar lo anterior plenamente lo ideal sería un examen pormenorizado de cómo es que las formas del montaje de la tabla de Metz - que él mismo llamó "la gran sintagmática del film narrativo" ${ }^{\prime 37}$ - generan, cada una situaciones de inferencia, es decir, que en el montaje - lo mismo que en la literatura - se dan todos los elementos para que al margen de cualquier habito cultural, de cualquier convención y, por tanto, de la artificialidad de un "lenguaje cinematográfico" - o del relato, como lo quiere Barthes -, la simple experiencia vital del espectador u observador cinematográfico le permita hacer inferencias - o comparaciones - y con ello entender el recital de eventos presentado en el filme. Por razones de espacio nos limitaremos a un examen somero de los ocho tipos de montaje que Metz consigna en su "gran sintagmática" de Metz.

Obviamente la película estándar en su conjunto es un solo gran montaje, pero dentro de él se pueden distinguir bloques o segmentos de sentido más o menos grandes, tales bloques son lo que Metz llama "los sintagmas" (FL 125) entendidos como "segmentos autónomos compuestos de varios planos" (FL 125). La noción de autonomía que impera aquí es, justamente la de un bloque de sentido unitario, y tal sentido unitario tiene que comprender en general a una situación de inferencia - o de comparación - natural que hace inteligible la relación entre los planos que forman tal bloque o segmento.

El tipo número 1 es, simplemente el "plano autónomo" (FL 124), el cuál no requiere de consideración especial dado que en realidad no es ningún montaje - por tanto realmente no es un "sintagma" (cfr. FL 124) - en lo absoluto sino una unidad que se encuentra en la película independiente de las secuencias que son realmente montaje, por ejemplo, los "insertos" (FL 125), que son de diferentes tipos.

Las comparaciones entre planos y series de planos reciben en Metz varios nombres de acuerdo con ciertas diferencias, y cubren los "tipos sintagmáticos" del 2 al 3 en su tabla. Nosotros los llamaremos simplemente formas de montaje comparativo y conllevan el que por lo menos una de las series de planos no contribuye a comprender la trama de la película - esto puede ser cierto incluso para todas las series de la comparación -. Con tal montaje se trata de subrayar

\footnotetext{
${ }^{37}$ Tal es el título del ensayo de Metz en AE, 146ss.
} 
una idea o bien sugerirla al espectador a través de la comparación de las series de planos, por ejemplo una serie de escenas de la vida de los pobres y otra serie mostrando la vida de los ricos (cfr. FL 125). Claro, resulta fácil entender la manera en la que un montaje como el recién escrito, sin contribuir al desarrollo de una trama simplemente da una ubicación de cierta problemática del filme, por lo menos la subraya. Dado que este tipo de montaje no contribuye al desarrollo de la trama - a lo más es redundante (cfr. 127) porque una de las series subraya una parte de la trama y, por tanto, podría ser eliminada de la película sin pérdida de inteligibilidad -, no implica ninguna situación de inferencia ni ningún elemento específico para ella, y remite a una inteligibilidad natural de la mera comparación de cosas o de relaciones que no requiere de ninguna convención como parte de la inteligibilidad de una película narrativa; aún fuera de una película tal, un caso así de montaje provoca las mismas comparaciones que en dicha película aunque inserta en ella pueda sugerir más cosas que aislada. Lo importante es, insistimos en ello, que dada la experiencia vital del espectador, este realiza de manera automática, natural, las comparaciones de las series de planos.

Consideremos ahora uno de los casos del tipo 4 de la tabla de Metz, a saber, el "sintagma descriptivo" (FL 127), en el cual todos los elementos que se presentan en la sucesión de planos corresponden a una existencia en "simultaneidad" (FL 127), más precisamente, a la relación de "coexistencia espacial" (FL 127). Metz pone el ejemplo de una secuencia en tanto "descripción de un paisaje (un árbol seguido por el plano de un río, seguido de la vista de una colina en la distancia, etc.)" (FL 127). En este caso es claro que aún cuando la secuencia "descriptiva" no formara parte de ninguna narración, de manera natural, dada la unidad, digamos, temática "diegética" - de los planos, el espectador inferiría que son vistas diferentes de un mismo entorno. Por otra parte, el “(...) sintagma descriptivo muy bien puede cubrir una acción, supuesto que su única relación interna inteligible sea de paralelismo espacial (...), es decir que el espectador no pueda entrelazar mentalmente [los planos secuencialmente] en el tiempo." (FL 128) Nótese que en este caso Metz se refiere a la imposibilidad de que el espectador piense - infiera - que se trata de diferentes momentos consecutivos de una misma acción, lo que quiere decir que el espectador infiere que se trata de diferentes ángulos de vista a la misma acción en el mismo momento. Nuevamente, no vemos aquí nada convencional, "codificado", sino simplemente una inteligibilidad natural que entrelaza los diferentes planos como diferentes aspectos de una acontecer en un mismo instante. Puede ser que quien nunca haya visto una secuencia tal quede desorientado por un instante, pero al percatarse de que en los diferentes planos aparecen los mismos elementos desde diferentes ángulos, rápidamente inferirá que "es lo mismo" visto desde diferentes ángulos. 
eNweva Etinenaxia Revista Digital de OFilosofia ISSN 1850-3578 2013 - Vol. 8 - Número VIII - Resistencia, Chaco, Argentina. Pp. 58 - 90

Muy en concordancia con la distinción propia del análisis literario entre narración y descripción, ${ }^{38}$ Metz pasa del "sintagma descriptivo" a los “(...) sintagmas narrativos, es decir, sintagmas en los cuales la relación temporal entre los objetos vistos en las imágenes contiene elementos de consecutividad y no únicamente de simultaneidad." (FL 128). El "sintagma narrativo alterno (o sintagma alterno)" (FL 128), que tradicionalmente se llama "montaje alterno", presenta series entrelazadas en las que algo sucede en sucesión temporal, por ejemplo, nos dice Metz, planos la huida de un perseguido entrelazados con planos de sus persecutores (cfr. FL 128). La idea aquí es que hay simultaneidad entre dos series de eventos. Nuevamente nos parece que lo mostrado por los planos no deja ninguna otra posibilidad para el espectador que la de inferir que se trata de un solo evento total que se desarrolla en el tiempo y del que se muestran aspectos diferentes y sucesivos.

Del "sintagma narrativo alterno" anterior debe ser distinguido el "sintagma narrativo lineal" (FL 128), el cual sería el sexto de los ocho "tipos sintagmáticos" de la tabla de Metz. Este nuevo tipo de montaje mostraría una sola acción o el desarrollo de una situación de manera cronológica, y esto puede ocurrir de manera continua o bien discontinua. En el primer caso se muestran aspectos de un desarrollo en su orden cronológico pero omitiendo ciertos otros aspectos, de manera tal que el tiempo mismo no se supone continuo. Por ejemplo, en un plano un hombre baja la escalara de una casa y en el siguiente plano el mismo hombre camina por la calle, por lo que el espectador infiere que el sujeto salió de su casa para ir a algún lado o a hacer algo; en este caso es claro que los eventos son consecutivos - eso infiere el espectador - aunque haya un salto temporal entre lo que ocurre en ambos planos. En el segundo caso se muestran distintos aspectos del desarrollo de un evento sin salto temporal, aunque sea desde diferentes ángulos. El caso típico de esto serían planos mostrando simultáneamente a dos personajes en una conversación cambiando el ángulo de los planos; la conversación nunca se interrumpe, el tiempo fluye de manera continua; eso es lo que infiere el espectador dado el contenido visual de los planos y el contenido de la cinta sonora. Metz se refiere a este mismo caso (cfr. FL 129) señalando incluso que “(...) la presencia en la cinta sonora de una sucesión coherente de declaraciones lingüísticas tiene el efecto de hacer más probable - aunque no obligatoria - una construcción (...) unitaria (...)” (FL 129). El solo hecho de que Metz mismo hable de lo que resulta más probable para el espectador muestra que se trata de una inteligibilidad natural, por inferencia en este caso, la que utiliza el espectador en la

\footnotetext{
${ }^{38}$ Véase por ejemplo el famoso ensayo de Lukács “¿Narrar o describir?”, en ER197ss.
} 
Q Nueva Etinexaxio Revista Digital de OFilosofia ISSN 1850-3578 2013 - Vol. 8 - Número VIII - Resistencia, Chaco, Argentina. Pp. 58 - 90

comprensión de la película. Todo al margen de cualquier la convencionalidad de cualquier código.

El caso de progresión de un desarrollo es especialmente importante porque muestra una homología con las inferencias en la vida real. Supongamos, por ejemplo, una secuencia en la que en el primer plano se presenta a un par de sujetos conversando en una oficina, un segundo plano en el que entra a dicha oficina el hijo de uno de los sujetos desesperado porque ha perdido una gran cantidad de dinero en juegos de azar y en el mismo plano el hijo abandona la oficina apresuradamente; en un tercer plano los dos sujetos iniciales se dirigen a la casa de aquel de ellos que es el padre del muchacho, en el cuarto plano ambos sujetos entran apresuradamente al estudio del padre en dicha casa y comprueban que en el cajón del escritorio del estudio ya no está la pistola que el padre guarda habitualmente en dicho cajón. Hasta ahí la secuencia. Es claro que el espectador infiere lo mismo que deberían haber inferido los sujetos iniciales, a saber, que el muchacho puede cometer suicidio. Bueno, pues lo mismo es lo que inferirían los sujetos en la vida real. Es decir, tanto en la situación ficticia presentada a través de una secuencia discontinua pero progresiva de eventos, como en la vida real, están dados todos los elementos para la inferencia de una posible desgracia, y eso al margen de toda convencionalidad, de toda "inteligibilidad adquirida" mediante el dominio de un código.

El ejemplo recién considerado tiene además la ventaja de permitirnos comprender que los planos fílmicos podrían ser substituidos por bloques de narración verbal correspondiendo al contenido de cada uno de ellos y que el lector haría la misma inferencia que los personajes iniciales de la narración y de la secuencia fílmica. Recuérdese aquí que, según vimos arriba, Barthes y Bremond suponen en lo esencial la existencia de una correspondencia entre los modos de estructuración del relato y posibilidades de la vida real, para postular la ambiciosa idea de una lingüística del relato y, concomitantemente, de una codificación de la existencia social. Lo cierto es que tanto en la vida real como en la literatura y en el cine, cadenas causales de eventos son inteligibles por sí solas de manera natural dado que corresponden a estructuras de inferencia que son lo más común y universal, al margen de todo código. En realidad, el "sintagma narrativo lineal" que Metz cree descubrir en el cine o las "funciones" del relato a las que se refieren autores como Barthes, son unidades de inteligibilidad natural, por inferencia, y no tienen nada que ver con ningún código, ni específicamente fílmico, ni de la "lengua del relato" de Barthes, ni con ninguna codificación de la experiencia social. Nótese que este último señalamiento complementa la discusión hecha atrás sobre el cuarto nivel códico, relativo a “(...) las grandes estructuras narrativas (en el sentido de Claude Bremond) que domina fuera de los filmes (pero también en ellos) en cada cultura (...)” (FL 62). 

2013 - Vol. 8 - Número VIII - Resistencia, Chaco, Argentina. Pp. 58 - 90

Los últimos dos "tipos sintagmáticos" de Metz son la "secuencia ordinaria" (FL 130) y la "secuencia episódica" (FL 130). Ambas suponen una sucesión cronológica con discontinuidad temporal. En la "secuencia ordinaria" se presentan fases de un desarrollo de largo plazo que no es parte de una acción, desarrollo que de esta manera resulta condensado. El ejemplo dado por Metz es el alejamiento entre el Sr. Kane y su esposa - en la famosa película de Orson Wells - presentado en escenas de desayuno cada vez más frías. La "secuencia episódica" presenta muy breves partes del desarrollo de un mismo episodio, es decir, de un suceso y no simplemente de un desarrollo de largo plazo -, dejando de lado aspectos del mismo. En el primer caso los sucesos están desorganizados en el sentido de que están dispersos en el tiempo; en el segundo forman el orden de progresión de un mismo episodio unitario (cfr. FL 130-1). En los dos casos es igualmente claro que si bien se trata de que hay "grandes diferencias entre la percepción fílmica y la percepción real" (FL 129), de todos modos no se trata de la artificialidad de un código, de algo análogo a la diferencia entre el orden lingüístico y la percepción, que no se trata de la "transforma[ción] del mundo en discurso" (FL 143), sino de que con base en las secuencias en cuestión el espectador infiere ciertas relaciones de tal manera que percepciones aisladas son entendidas como partes de un mismo desarrollo.

El último punto debe ser subrayado ya que es común que las situaciones de inferencia reconstruyan o proyecten un orden del mundo que no corresponde directamente a la percepción, por ejemplo, cuando un cazador encuentra la huella de un animal de tal manera que infiere que este está en las cercanías; de hecho es muy común que las situaciones de inferencia hacia el pasado y hacia el futuro no correspondan a la experiencia perceptiva realmente acaecida. En otras palabras no porque algo se entienda sin ser visto, porque algo se entienda "omitiendo" (FL 132) aspectos de ello, eso quiere decir que en la inteligibilidad de lo que ocurre opere código alguno, una "inteligibilidad adquirida", realmente artificial. Uno entiende muchas cosas sin verlas directamente y la parcialidad de un plano o de una secuencia de planos respecto de la realidad - por ejemplo mediante las muy conocidas inversiones fílmicas del orden de la presentación en el montaje respecto del orden temporal que indica la lógica de los acontecimientos - , la distancia entre la inteligibilidad del film y la percepción directa de los desarrollos reales, no significa, ni lejanamente, que el film sea un sistema de inteligibilidad distinto de las inferencias que haría cualquier testigo de un desarrollo real a partir de fragmentos de "información" - ya sea visual, como en el caso de videos policíacos, o verbal, como en el caso de informaciones de testigos e, incluso, en el caso de la pseudo información dada por una narración literaria -. 
Q Nueva Etinexaxio Revista Digital de OFilosofia ISSN 1850-3578 2013 - Vol. 8 - Número VIII - Resistencia, Chaco, Argentina. Pp. 58 - 90

\section{Conclusión}

Metz reconoce hasta cierto punto la idea subyacente a nuestra última observación, ya que nos dice que "[l]os tipos sintagmáticos en los cuales la denotación no es análoga [es decir, en los cuales el "significado" del montaje no corresponde directamente a lo que se ve en los planos] mantienen un cierto grado de naturalidad en la relación del significante [el montaje] con el significado [lo inteligible a partir del montaje]." (FL 135, c. a.) Por ello, por lo menos en algún caso de montaje, Metz nos dice que "(...) solamente podemos hablar de codificación parcial." (FL 136) Por otra parte,

"[e]ntre las estructuras de imágenes que son posibles (...), solamente unas pocas están convencionalizadas; entre los patrones de inteligibilidad más o menos naturales (los lógicos) con base en los cuales el cine podría construir sus ordenamientos sintagmáticos, solamente se utilizan unos pocos - y se convierten en patrones efectivos de intelección y casi siempre son entendidos por el espectador normal, adulto, de una sociedad familiarizada con el cine. Es sorprendente que, en relación con todos los ordenamientos de imágenes que son concebibles, solamente un número muy reducido de ellos se use realmente. Justamente como en la semántica se da la arbitrariedad de la lexicalización, en el cine se tiene la arbitrariedad de la gramaticalización." (FL 136)

El párrafo recién citado es notable porque parece encerrar la contradicción de que en él se reconoce la naturalidad - al menos parcial - de la inteligibilidad de los patrones de imágenes que "realmente" se usan en el montaje, pero se acaba diciendo que en esos "ordenamientos" hay una "arbitrariedad de la gramaticalización", lo que podría querer decir una arbitrariedad del arreglo de los planos en el montaje. Nótese que la única manera de huir de la contradicción es interpretar la supuesta "arbitrariedad" no diciendo que esta concierne al arreglo, sino solamente a la elección de un arreglo de entre otros posibles. En otras palabras, en realidad la idea de Metz no es que el arreglo de los planos, el montaje, sea arbitrario, sino que lo que es arbitrario es que se elija un tipo dado de arreglo. La "gramaticalización", con la noción inevitable de arbitrariedad que conlleva este término, no está en los tipos de montaje, ya que estos son "patrones de inteligibilidad más o menos naturales", "efectivos", sino en la elección del conjunto de patrones de entre los muchos que, supuestamente, serían posibles.

En realidad esta tesis de Metz no es convincente porque a) no acaba de quedar claro que realmente existan muchos patrones de inteligibilidad más allá de los que realmente se utilizan. Tal vez otras formas del montaje ya no sean tan inteligibles como las que se ponen en práctica y por lo que habría que hacer una convención para determinar su significado; por supuesto, por parte del público tendría que darse un aprendizaje para poder entender dichos tipos de 
eNweva Etinenaxia Revista Digital de OFilosofia ISSN 1850-3578 2013 - Vol. 8 - Número VIII - Resistencia, Chaco, Argentina. Pp. 58 - 90

montaje y, con él, la película que lo integrase. Pero por sobre todo, la tesis no es convincente porque, además, en las gramaticalizaciones verdaderas, las de los códigos, por ejemplo los lingüísticos, si que hay una arbitrariedad esencial, como la de tener artículos o no, como la de tener un número mayor o menor de casos gramaticales, de géneros, como la de colocar verbos en diferentes posiciones dentro de la frase, etc. Todas estas elecciones son una verdadera convención, no hay nada natural que las haga necesarias, sin embargo, las "posibles" formas del montaje sí que deben ser inteligibles en sí mismas, portan la naturalidad de la inteligibilidad esencial de las situaciones vitales al margen del lenguaje y de todo otro código. La existencia no es codificada y el cine solamente la emula de manera básicamente visual como la literatura la emula de manera verbal -.

Creemos que con lo anterior que caro que la idea estándar, tal como la esbozó y desarrollo Metz, de una "semiótica cinematográfica" con base en los modelos de la lingüística estructural de origen saussuriano, resulta poco sostenible y alejada del verdadero tipo de intelección movilizado por la experiencia cinematográfica. En síntesis, es muy dudoso que en la experiencia cinematográfica - fuera de la banda sonora propiamente lingüística o de los insertos textuales, así como de la reproducción fílmica de verdaderos elementos codificados como señales de tráfico, etc. - jueguen papel relevante códigos de algún tipo. No nos parece, pues, que realmente exista - con las excepciones recién mencionadas - ninguno de los niveles de codificación a los que se refiere Metz. Por supuesto, en este sentido ni hay un "lenguaje cinematográfico" que remita a una codificación parcial amplia, ni tampoco hay ni "mensaje", ni "sintagma", ni "discurso", ni "texto cinematográfico", con lo que la empresa completa de la "semiótica cinematográfica" tal como la propone Metz en su manera clásica nos parezca extremadamente problemática. Pensamos que más bien la experiencia cinematográfica como la literaria - se basa en la generación de situaciones de inteligibilidad a partir de emulaciones visuales de la vida, por lo que la aproximación más adecuada a dicha experiencia puede tomar mucho de la ciencia cognitiva y la filosofía de la mente.

\section{Bibliografía y abreviaturas}

AR = Barthes, R., "Introducción al análisis estructural de los relatos" (1966), en: Niccolini, S., El análisis estructural, Tiempo Contemporáneo, Buenos Aires, 1977.

FS = Barthes, R., The Fashion System (1967), University of California, California, 1990.

$\mathrm{AE}=$ Bremond, C., "La lógica de los posibles narrativos", en: Verón, E., Análisis estructural del relato, Tiempo Contemporáneo, Buenos Aires, 1970.

NM = Dretske, F., Naturalizing the Mind, MIT, Cambridge, 1997. 
Q Nueva Etinexaxio Revista Digital de OFilosofia ISSN 1850-3578 2013 - Vol. 8 - Número VIII - Resistencia, Chaco, Argentina. Pp. 58 - 90

EU = Hume, D., An Enquiry Concerning Human Understanding (1748), Oxford, 2007.

ER = Lukács, G., Essais über Realismus (1971), obras completas, vol. 4, Luchterhand, Berlín, 1971.

KrV = Kant, I., Kritik der reine Vernunft (1781), Felix Meiner, Hamburgo, 1971.

IB = Lipton, P., "Inference to the Best Explanation", en: Newton-Smith, A Compation to the Philosophy of Science, Blackwell, 2000.

$\mathrm{FL} \quad=$ Metz, Ch., Film Language. A Semiotics of Cinema (1968), University of Chicago, 1991.

LC = Metz, Ch., Lenguaje and Cinema (1974), Mouton, the Hague, 1974.

$\mathrm{EP} \quad=$ Peirce, Ch. S., The Essential Peirce. Selected Philosophical Writings, vol. 2 (1893 1913), Indiana, 1998.

WO = Quine, W. V. O., Word and Object (1960), MIT, Cambridge, 1960.

NV = Stam, R., et al, New Vocabularies in Film Semiotics. Structuralism, Post-Structuralism and Beyond (1992), Routledge, London and New York, 1999. 